Scientific journal

PHYSICAL AND MATHEMATICAL EDUCATION

Has been issued since 2013.

Науковий журнал

ФІЗИКО-МАТЕМАТИЧНА ОСВІТА

Видається з 2013.
ISSN 2413-158X (online)
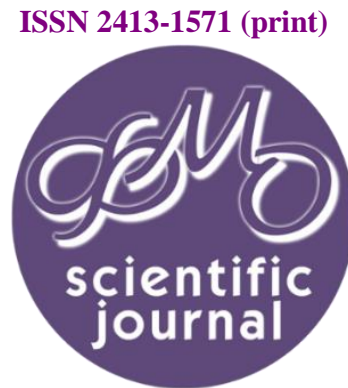

\title{
http://fmo-journal.fizmatsspu.sumy.ua/
}

Воскоглу Майкл Гр. Застосування рівнянь нечітких відношень до оцінки умінь розв'язувати аналогічні задачі. Фізикоматематична освіта. 2018. Випуск 1(15). С. 122-127.

Voskoglou M. Application Of Fuzzy Relation Equations To Assessment Of Analogical Problem Solving Skills. Physical and Mathematical Education. 2018. Issue 1(15). P. 122-127.

Michael Gr. Voskoglou

Graduate Technological Educational Institute of Western Greece, Patras, Greece voskoglou@teiwest.gr;mvosk@hol.gr DOI 10.31110/2413-1571-2018-015-1-021

\section{APPLICATION OF FUZZY RELATION EQUATIONS TO ASSESSMENT OF ANALOGICAL PROBLEM SOLVING SKILLS}

Abstract. Analogical reasoning is a very important part of the human cognition in general for creativity and scientific discovery and in particular it is a very useful method for solving mathematical problems by retrieving from the memory similar problems solved in the past and adapting their solutions for use with the target problem. On the other hand, the student assessment is an essential task of Education, because, apart of being a social need and demand, it helps the instructors in designing their future plans for a more effective teaching procedure. However, frequently an instructor is not sure about the exact grade corresponding to each student's performance. Therefore, the student assessment is characterized by a degree of vagueness and/or uncertainty. Consequently, fuzzy logic, due to its property of characterizing the ambiguous real life situations with multiple values, becomes a reach resource of assessment techniques to be applied in such vague cases. In this work fuzzy relation equations are used as a tool for evaluating student analogical problem solving skills. The fuzzy relation equations are obtained by the composition of binary fuzzy relations, which are fuzzy sets defined on the Cartesian product of two crisp sets. The compositions of binary fuzzy relations are conveniently performed in terms of the membership matrices of them. The same elements of the membership matrices are used in these compositions as would be used in the regular multiplication of matrices, but the product and sum operations are here replaced with the min and max operations respectively. The notion of fuzzy relation equations was first proposed by Sanchez in 1976 and later was further investigated by other researchers. A classroom application and other suitable examples are also presented in this article illustrating our results. Further, the present work is connected to our earlier research efforts on utilizing several other fuzzy Logic techniques as tools for the assessment of the student performance.

Keywords: Fuzzy Sets (FS), Fuzzy Binary Relations (FBR), Fuzzy Relation Equations (FRE), Analogical Reasoning (AR), Analogical Problem Solving (APS), Student Assessment.

Problem formulation. The student assessment is a very important task of Education, because apart of being a social need and demand it helps the instructors in designing their future plans for a more effective teaching procedure. When the student performance is evaluated by numerical scores, the traditional method to assess the mean performance of a student class is the calculation of the average of those scores. However, either for reasons of more elasticity or to comfort the teacher's existing uncertainty about the exact value of the numerical scores corresponding to each student's performance, frequently in practice the assessment is made not by numerical scores but by linguistic grades, like excellent, very good, good, etc. This involves a degree of vagueness and makes the calculation of the mean value of grades impossible.

A popular in such cases method for evaluating the overall performance of a student class is the calculation of the Grade Point Average (GPA) index (e.g. see [19], Chapter 6, p.125). GPA is a weighted average in which greater coefficients (weights) are assigned to the higher grades, which means that it reflects not the mean, but the quality performance of a student class.

In an effort to evaluate the mean student performance in such vague assessment cases, we have used in earlier works tools from Fuzzy Logic. More explicitly, representing a student class as a fuzzy set in the set of the linguistic grades assessing the student performance, we calculated the existing in it probabilistic or possibilistic uncertainty (e.g. Chapter 5 of [19]). This approach is based on the classical principle of Information Theory that the greater is the reduction of the existing uncertainty following a student activity (e.g. test, problem-solving, learning a new subject matter, etc.), the more the new information obtained by the class and therefore the better its performance. However, this method has two disadvantages: First it involves laborious calculations and second it can be used for comparing the mean performance of two different classes only under the assumption that they have been proved to have equivalent skills before the corresponding activity, a condition that frequently does not hold in practice.

Motivated by those disadvantages, we have used in later works Triangular or Trapezoidal Fuzzy Numbers for assessing the student mean performance (e.g. see Chapter 7 of [19]), a method that has been proved to be simpler and more accurate than the calculation of the uncertainty. 
On the other hand, Subbotin et al. [12], based on a fuzzy model that we had developed in an earlier work for studying the process of learning a subject matter in the classroom [17], they properly adapted the popular in fuzzy mathematics Centre of Gravity defuzzification technique for evaluating the student quality performance. This model was later named as the Rectangular Fuzzy Assessment Model, while Subbotin and his collaborators developed also several variations of it by changing the shape of the graph of the corresponding membership function (e.g. see [13-16], Chapter 6 of [19], etc.)

Here a new approach will be developed involving the use of Fuzzy Relation Equations (FRE) for evaluating the student Analogical Reasoning (AR) skills for solving mathematical problems. The rest of the paper is formulated as follows: A brief account about the AR process is given in the second section. The third section contains the background from Fuzzy Binary Relations (FBR) and FRE which is necessary for the understanding of the paper. In the fourth section the model that uses FRE for studying the process of Analogical Problem Solving (APS) is developed, whereas in the fifth section a classroom application and other suitable examples are presented illustrating our new assessment model. Finally, the sixth section is devoted to our conclusion and to some hints for future research on the subject, whereas the problems used in our classroom application are exposed in the Appendix at the end of the paper.

Analogical reasoning. Analogies are used for explaining concepts which cannot directly perceived (e.g. electricity in terms of the water flow), in making predictions within domains, in communication and persuasion, etc. AR is a method of processing information that compares the similarities between new and past understood concepts, then using these similarities to gain understanding of the new concept. AR is important in general for creativity and scientific discovery. Within cognitive science mental processes are likened to computer programs (e.g. neural networks) and such analogies serve as mental models to support reasoning in new domains [4].

APS is the main mechanism of AR: When the solver is not sure of the appropriate procedure to solve a given problem (target problem), a good hint would be to look for a similar problem solved in the past (source problem) and then try to adapt the solution procedure of this problem for use with the target problem. However this strategy can be difficult to implement in problem solving, because it requires the solver to attend to information other than the problem to be solved. Thus the solver may come up empty-handed, either because he/she has not solved any similar problems in past, or because he/she fails to realize the relevance of previous problems. But, even if an analogue is retrieved, the solver must know how to use it to determine the solution procedure for the target problem.

Several studies $([2,3,6,9,18]$, etc.) have provided detailed models for the AR process based on APS, in which factors associated with instances of successful transfer of knowledge are identified. According to these studies the main steps involved in APS include:

- $S_{1}$ : Representation of the target problem.

- $S_{2}$ : Search-retrieval of a source problem

- $S_{3}$ : Mapping of the representations of the target and the source problem.

- $\boldsymbol{S}_{4}$ : Adaptation of the solution of the source problem for use with the target problem.

More explicitly, before solvers working on a problem they usually construct a representation of it. A good representation must include both the surface and the structural (abstract, solution relevant) features of the problem. The former are mainly determined by what are the quantities involved in the problem and the latter by how these quantities are related to each other. The features included in solver representations of the target problem are used as retrieval cues for a source problem in memory. When the two problems share structural (solution relevant) but not surface features the source is called a remote analogue of the target problem. Analogical mapping requires aligning the two situations, i.e. finding the correspondences between the representations of the target and the source problem, and projecting inferences from the source to the target. Once the common alignment and the candidate inferences have been discovered the analogy is evaluated. The last step involves the adaptation of the solution of the analogous problem for use with the target problem, where the correspondences between objects and relations of the two problems must be used.

The successful completion of the above process is referred as positive AR. But the search may also yield distracting problems sharing surface but not structural common features with the target problem and therefore being only superficially similar to it. Usually the reason for this is a non satisfactory representation of the target problem, containing only its salient surface features, and the resulting consequences on the retrieval cues available for the search process. When a distracting problem is considered as an analogue of the target, we speak about negative $\boldsymbol{A R}$. This happens if a distracting problem is retrieved as a source problem and the solver fails, through the mapping of the representations of the source and target problem, to realize that the source cannot be considered as an analogue to the target problem.

Fuzzy relation equations. Let $U$ be the universal set of the discourse. It is recalled that a Fuzzy Set (FS) A in $U$ is a set of ordered pairs of the form

$$
A=\{(x, m(x)): x \in U\},
$$

where $\mathrm{m}: \mathrm{U} \rightarrow[0,1]$ is the membership function defining $A$. The value $\mathrm{m}(\mathrm{x})$ is called the membership degree of $\mathrm{x}$ in $\mathrm{A}$. The closer is $m(x)$ to 1 , the better $x$ satisfies the characteristic property of A. For example, if $A$ is the FS of the old people of a city and $m(x)=0.7$, then $x$ is a rather old inhabitant of the city, etc. For general facts on fuzzy sets we refer to the book [8].

Definition 1: Let $X, Y$ be two crisp sets. Then a FBR $R(X, Y)$ is a FS on the Cartesian product $X \times Y$ of the form:

$$
R(X, Y)=\left\{\left(r, m_{R}(r): r=(x, y) \in X x Y\right\},\right.
$$

where $m_{R}: X x Y \rightarrow[0,1]$ is the corresponding membership function.

When $X=\left\{x_{1}, \ldots \ldots . . ., X_{n}\right\}$ and $Y=\left\{y_{1}, \ldots \ldots ., Y_{m}\right\}$, then a FBR $R(X, Y)$ can be represented by a $n X m$ matrix of the form:

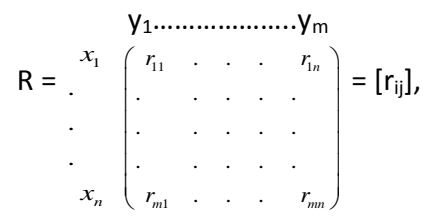


where $r_{i j}=m_{R}\left(x_{i}, y_{j}\right)$, with $i=1, \ldots, n$ and $j=1, \ldots, m$. The matrix $R$ is called the membership matrix of the fuzzy relation $R(X, Y)$.

The basic ideas of fuzzy relations, which were introduced by Zadeh [20] and were further investigated by other researchers, are extensively covered in the book [7].

Definition 2: Consider two $\mathrm{FBR} P(\mathrm{X}, \mathrm{Y})$ and $\mathrm{Q}(\mathrm{Y}, \mathrm{Z})$ with a common set $\mathrm{Y}$. Then, the standard composition of these relations, which is denoted by

$P(X, Y) \circ Q(Y, Z)$ produces a $F B R R(X, Z)$ with membership function $m_{R}$ defined by:



for all $\mathrm{i}=1, \ldots, \mathrm{n}$ and all $\mathrm{j}=1, \ldots, \mathrm{m}$. This composition is usually referred as max-min composition.

Compositions of FBR are conveniently performed in terms of the membership matrices of them. In fact, if $P=\left[p_{i k}\right]$ and $Q=\left[q_{k j}\right]$ are the membership matrices of the $\operatorname{FBR} P(X, Y)$ and $Q(Y, Z)$ respectively, then by relation (1) we get that the membership matrix of $R(X, Y)=P(X, Y) \circ Q(Y, Z)$ is the matrix $R=\left[r_{i j}\right]$, with

$$
\mathrm{r}_{\mathrm{ij}}=\underset{k}{\operatorname{Max}} \min \left(p_{i k}, q_{k j}\right)
$$

Example 1:

$$
\begin{aligned}
& \begin{array}{lllllll}
y_{1} & y_{2} & y_{3} & z_{1} & z_{2} & z_{3} & z_{4}
\end{array} \\
& \text { If } \mathrm{P}=\begin{array}{r}
x_{1} \\
x_{2} \\
x_{2}
\end{array}\left(\begin{array}{ccc}
0.2 & 0.4 & 0.8 \\
0.1 & 0.5 & 1 \\
0.4 & 0.7 & 0.3
\end{array}\right) \text { and } \mathrm{Q}=\begin{array}{l}
\mathrm{y}_{1} \\
\mathrm{y}_{2} \\
\mathrm{y}_{2}
\end{array}\left(\begin{array}{cccc}
0.2 & 0.7 & 0 & 0.4 \\
0.8 & 0.1 & 0.5 & 0.6 \\
1 & 0.3 & 0.2 & 0.9
\end{array}\right) \text { are the membership matrices of } \mathrm{P}(\mathrm{X}, \mathrm{Y}) \text { and } \mathrm{Q}(\mathrm{Y}, \mathrm{Z}) \text { respectively, }
\end{aligned}
$$

then by relation (2) the membership matrix of $R(X, Z)$ is the matrix

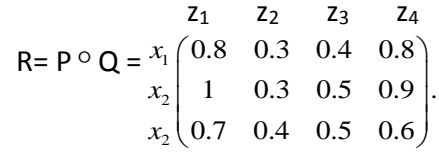

Observe that the same elements of $P$ and $Q$ are used in the calculation of $m_{R}$ as would be used in the regular multiplication of matrices, but the product and sum operations are here replaced with the $\mathrm{min}$ and max operations respectively.

Definition 3: Consider the FBR $P(X, Y), Q(Y, Z)$ and $R(X, Z)$, defined on the sets, $X=\left\{x_{i}: i \in N_{n}\right\}, Y=\left\{y_{j}: j \in N_{m}\right\}, Z=\left\{z_{k}: k \in\right.$ $N s\}$, where $N_{t}=\{1,2, \ldots, t\}$, for $t=n, m, k$, and let $P=\left[p_{i j}\right], Q=\left[q_{j k}\right]$ and $R=\left[r_{i k}\right]$ be the membership matrices of $P(X, Y), Q(Y, Z)$ and $R(X$, $Z)$ respectively. Assume that the above three relations constrain each other in such a way that

$$
P \circ Q=R \text {, }
$$

where $\circ$ denotes the max-min composition. This means that

$$
M \underset{j \in J}{\operatorname{ax}} \min \left(\mathrm{p}_{\mathrm{ij}}, \mathrm{q}_{\mathrm{jk}}\right)=\mathrm{r}_{\mathrm{ik}},
$$

for each i in $\mathrm{N}_{n}$ and each $\mathrm{k}$ in $\mathrm{N}_{s}$. Therefore the matrix equation (3) encompasses $\mathrm{nXs}$ simultaneous equations of the form (4). When two of the components in each of the equations (4) are given and one is unknown, these equations are referred as FRE.

The notion of FRE was first proposed by Sanchez [11] and later was further investigated by other researchers $[1,5,10]$.

A study of AR skills using FRE. Let us consider the crisp sets $X=\{M\}$,

$Y=\{A, B, C, D, F\}$ and $Z=\left\{S_{1}, S_{2}, S_{3}, S_{4}\right\}$, where $M$ denotes the imaginary notion of the average student of a class, $A=$ Excellent, $B=$ Very Good, $C=$ Good, $D=$ Fair and $F=$ Failed are the linguistic grades used for the assessment of the student performance and $S_{i}, i=1,2,3,4$ are the steps of the APS process.

Further, let $n$ be the total number of students of a certain class and let $n_{i}$ be the numbers of students who obtained the grade $\mathrm{i}$ assessing their performance, $\mathrm{i} \in \mathrm{Y}$. Then one can represent the average student of the class as a FS on $\mathrm{Y}$ in the form

$$
\mathrm{M}=\left\{\left(\mathrm{i}, \frac{n_{i}}{n}\right): \mathrm{i} \in \mathrm{Y}\right\}
$$

The FS M induces a FBR $\mathrm{P}(\mathrm{X}, \mathrm{Y})$ with membership matrix

$$
\mathrm{P}=\left[\frac{n_{A}}{n} \frac{n_{B}}{n} \frac{n_{C}}{n} \frac{n_{D}}{n} \frac{n_{F}}{n}\right]
$$

In an analogous way the average student of a class can be represented as a FS on $Z$ in the form

$$
M^{\prime}=\left\{\left(S_{j}, m\left(S_{j}\right): S_{j} \in Z\right\},\right.
$$

where $\mathrm{m}: \mathrm{Z} \rightarrow[0,1]$ is the corresponding membership function. In this case the $F S M^{\prime}$ induces a $F B R R(X, Z)$ with membership matrix

$$
R=\left[m\left(S_{1}\right) m\left(S_{2}\right) m\left(S_{3}\right) m\left(S_{4}\right)\right] .
$$

We consider also the FBR $Q(Y, Z)$ with membership matrix the $5 X 4$ matrix

$Q=\left[q_{i j}\right]$, where $q_{i j}=m_{Q}(i, j)$ with $i \in Y$ and $j \in Z$ and the FRE encompassed by the matrix equation (3), i.e. by $P \circ Q=R$.

When the matrix $Q$ is fixed and the row-matrix $P$ is known, then the equation (3) has always a unique solution with respect to $\mathrm{R}$, which enables the representation of the average student of a class as a FS on the set of the steps of the MM process. This is useful for the instructor for designing his/her future teaching plans.

On the contrary, when the matrices $Q$ and $R$ are known, then the equation (3) could have no solution or could have more than one solution with respect to $P$, which makes the corresponding situation more complicated.

A classroom application and other examples. The new assessment model presented in the previous section will be illustrated here with a classroom application on APS and two other examples.

The Classroom Application: The following experiment took place at the Graduate Technological Educational Institute of Western Greece, in the city of Patras, with subjects a group of 60 students of the School of Technological Applications (future engineers) being at their first term of studies. Three mathematical problems were given for solution to students on topics of their first term course in mathematics. In each case and before receiving the target problem the students received two other problems 
together with their solution procedures. They read each problem and its solution procedure and then solved the problem themselves using the given procedure. Subjects were allowed 10 minutes for each problem and they were not given the other problem until after 10 minutes had elapsed. The first of these problems was a remote analogue to the target problem, while the other was a distracting problem. Next the target problem was given and was asked from the students to try to solve it by adapting the solution of one of the previous problems (time allowed 20 minutes). The problems given to students are listed in the Appendix at the end of the paper. The results of the test are depicted in Table 1.

According to those results the average student $M$ of the class can be represented as a fuzzy set on $Y=\{A, B, C, D, F\}$ by

$$
\begin{aligned}
& M=\left\{\left(A, \frac{20}{60}\right),\left(B, \frac{15}{60}\right),\left(C, \frac{7}{60}\right),\left(D, \frac{10}{60}\right),\left(F, \frac{8}{60}\right)\right\} \\
& \approx\{(A, 0.33),(B, 0.25),(C, 0.12),(D, 0.17),(F, 0.13)\}
\end{aligned}
$$

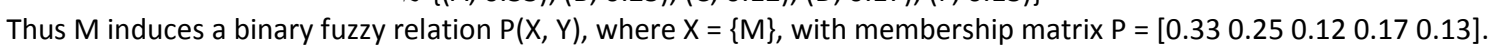

\section{Student Performance}

Table 1.

\begin{tabular}{|c|c|}
\hline Grade & No. Of Students \\
\hline A & 20 \\
\hline B & 15 \\
\hline C & 7 \\
\hline D & 10 \\
\hline F & 8 \\
\hline Total & 60 \\
\hline
\end{tabular}

Also, using statistical data of the last five academic years about the APS skills of the students of the School of Technological Applications of the Graduate Technological Educational Institute of Western Greece, we fixed the membership matrix $Q$ of the binary fuzzy relation $Q(Y, Z)$, where $Z=\left\{S_{1}, S_{2}, S_{3}, S_{4}\right\}$, in the form:

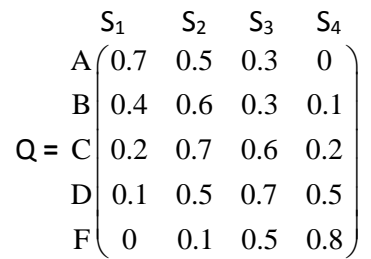

The statistical data used to form the matrix $Q$ were collected by the instructor who was inspecting the student reactions during the solution of several problems in the classroom with the method of AR.

Next, using the max-min composition of FBR one finds that the membership matrix of $R(X, Z)=P(X, Y) \circ Q(Y, Z)$ is equal to

$$
R=P \circ Q=\left[\begin{array}{llll}
0.33 & 0.33 & 0.30 .17
\end{array}\right] \text {. }
$$

Therefore the average student of the class can be expressed as a fuzzy set on $\mathrm{Z}$ by

$$
M^{\prime}=\left\{\left(S_{1}, 0.33\right),\left(S_{2}, 0.33\right),\left(S_{3}, 0.3\right),\left(S_{4}, 0.17\right)\right\} \text {. }
$$

The conclusions obtained from the above expression of $\mathrm{M}^{\prime}$ are the following:

- Only the $\frac{1}{3}$ of the students constructed good representations of the target problems.

$$
\overline{3}
$$

- All the above students were able to retrieve source problems and almost all of them mapped the representations of the target and the source problems.

- On the contrary, half of the above students failed to adapt the solution of the source for solving the target problems.

The first conclusion was not surprising at all, since the majority of the students have the wrong habit to start studying the material of their courses the last month before the final exams. On the other hand, the second conclusion shows that the instructor's teaching procedure of AR was in a degree successful enabling the diligent students to retrieve source problems from their memories and to map the representations of the target and the source problems. Finally, the last conclusion is due to the fact that many of those students, being inexperienced, failed through the mapping of the representations of the source and target problem to realize that the selected source cannot be considered as an analogue to the target problem (negative AR) Therefore, it is very useful for the instructor to emphasize during his/her lectures the importance of mapping for APS for controlling the fitness of the source problem.

Let us now consider the case where the membership matrices $Q$ and $R$ are known and we want to determine the matrix $\mathrm{P}$ representing the average student of the class as a fuzzy set on $\mathrm{Y}$. This is a complicated case because we may have more than one solution or no solution at all. The following two examples illustrate this situation:

Example 2: Consider the membership matrices $Q$ and $R$ of the previous application and set $P=\left[p_{1} p_{2} p_{3} p_{4} p_{5}\right]$.

Then the matrix equation $\mathrm{P} \circ \mathrm{Q}=\mathrm{R}$ encompasses the following equations:

$\max \left\{\min \left(p_{1}, 0.7\right), \min \left(p_{2}, 0.4\right), \min \left(p_{3}, 0.2\right), \min \left(p_{4}, 0.1\right), \min \left(p_{5}, 0\right)\right\}=0.33$

$\max \left\{\min \left(p_{1}, 0.5\right), \min \left(p_{2}, 0.6\right), \min \left(p_{3}, 0.7\right), \min \left(p_{4}, 0.5\right), \min \left(p_{5}, 0.1\right)\right\}=0.33$

$\max \left\{\min \left(p_{1}, 0.3\right), \min \left(p_{2}, 0.3\right), \min \left(p_{3}, 0.6\right), \min \left(p_{4}, 0.7\right), \min \left(p_{5}, 0.5\right)\right\}=0.3$

$\max \left\{\min \left(p_{1}, 0\right), \min \left(p_{2}, 0.1\right), \min \left(p_{3}, 0.2\right), \min \left(p_{4}, 0.5\right), \min \left(p_{5}, 0.8\right)\right\}=0.17$

The first of the above equations is true if, and only if, $p_{1}=0.33$ or $p_{2}=0.33$, values that satisfy the second and third equations as well. Also, the fourth equation is true if, and only if, $p_{3}=0.17$ or $p_{4}=0.17$ or $p_{5}=0.17$. Therefore, any combination 
of values of $p_{1}, p_{2}, p_{3}, p_{4}, p_{5}$ in $[0,1]$ such that $p_{1}=0.33$ or $p_{2}=0.33$ and $p_{3}=0.17$ or $p_{4}=0.17$ or $p_{5}=0.17$ is a solution of $P \circ Q=R$.

Let $S(Q, R)=\{P: P \circ Q=R\}$ be the set of all solutions of $P \circ Q=R$. Then one can define a partial ordering on $S(Q, R)$ by

$$
\mathrm{P} \leq \mathrm{P}^{\prime} \Leftrightarrow \mathrm{p}_{\mathrm{i}} \leq \mathrm{p}_{\mathrm{i}}^{\prime}, \forall \mathrm{i}=1,2,3,4,5 \text {. }
$$

It is well established that whenever $S(Q, R)$ is a non empty set, it always contains a unique maximum solution and it may contain several minimal solutions [11]. It is further known that $S(Q, R)$ is fully characterized by the maximum and minimal solutions in the sense that all its other elements are between the maximal and each of the minimal solutions [11]. A method of determining the maximal and minimal solutions of $P \circ Q=R$ with respect to $P$ has been developed in [5].

Example 3: Let $Q=\left[q_{i j}\right], i=1,2,3,4,5$ and $j=1,2,3,4$ be as in Example 2 and let $R=\left[\begin{array}{llll}1 & 0.33 & 0.3 & 0.17\end{array}\right]$. Then the first equation encompassed by the matrix equation $P \circ Q=R$ is $\max \left\{\min \left(p_{1}, 0.7\right), \min \left(p_{2}, 0.4\right), \min \left(p_{3}, 0.2\right), \min \left(p_{4}, 0.1\right),\left(p_{5}, 0\right)\right\}=1$.

In this case it is easy to observe that the above equation has no solution with respect to $p_{1}, p_{2}, p_{3}, p_{4}, p_{5}$, therefore $P \circ Q=R$ has no solution with respect to $P$.

In general, writing $R=\left\{r_{1} r_{2} r_{3} r_{4}\right\}$, it becomes evident that we have no solution if $\max q_{i j}<r_{j}$.

Conclusion. In the present article we used FRE for assessing student APS skills. In this way we have managed to express the "average student" of a class as a FS on the set of the steps of the AR process, which gives valuable information to the instructor for designing his/her future teaching plans. On the contrary, we have realized that the problem of representing the "average student" of a class as a fuzzy set on the set of the linguistic grades characterizing his performance using FRE is complicated, since it may have more than one solutions or no solution at all.

In general, the use of FRE looks as being a powerful assessment method. Therefore our future research plans on the subject will be oriented to the effort of using FRE for evaluating other human or computer activities (apart from AR), like learning, sports and spiritual games, decision-making, , case-based reasoning, etc.

Appendix. The problems of the classroom application

\section{CASE 1}

Target problem: A box contains 8 balls numbered from 1 to 8 . One makes three successive drawings, putting back the corresponding ball to the box before the next drawing. Find the probability of getting all the balls drawing out of the box different to each other.

Solution: The probability is equal to the quotient of the total number of the ordered samples of 3 objects from 8 (favourable outcomes) to the total number of the corresponding samples with replacement (possible outcomes).

Remote analogue: How many numbers of 2 digits can be formed by using the digits from 1 to 6 and how many of them have their digits different?

Solution procedure given to the students: Find the total number of the ordered samples of 2 objects from 6 with and without replacement respectively.

Distracting problem: A box contains 3 white, 4 blue and 6 black balls. If we draw out 2 balls, what is the probability to be of the same colour?

Solution procedure given to the students: The number of all favourable outcomes is equal to the sum of the total number of combinations of 3,4 and 6 objects taken 2 at each time respectively, while the number of all possible outcomes is equal to the total number of combinations of 13 objects taken 2 at each time.

\section{CASE 2}

Target problem: Consider the matrices:

$A=\left[\begin{array}{ccc}1 & -a ́ & -a ́ \\ 0 & 1 & -a ́ \\ 0 & 0 & 1\end{array}\right]$ and $B=\left[\begin{array}{ccc}0 & -a ́ & -a ́ \\ 0 & 0 & -a ́ \\ 0 & 0 & 0\end{array}\right]$

Prove that $\mathrm{A}^{n}=\mathrm{A}+(n-1)\left(\mathrm{B}+\frac{n}{2} \mathrm{~B}\right)$, for every positive integer $n$. -

Solution: Since $A=1+B$, where I stands for the unitary $3 \times 3$ matrix, and $\mathrm{B}^{3}=0$, is $\mathrm{A}^{n}=(1+\mathrm{B})^{\mathrm{n}}=1+n \mathrm{~B}+\frac{n(n-1)}{2} \mathrm{~B}^{2}=$ $=\mathrm{A}+(n-1) \mathrm{B}+\frac{n(n-1)}{2} \mathrm{~B}=\mathrm{A}+(n-1)\left(\mathrm{B}+\frac{n}{2} \mathrm{~B}\right)$.

Remote analogue: Let $\alpha$ be a nonzero real number. Prove that $\alpha^{n}=\sum_{i=0}^{n}\left(\begin{array}{l}n \\ i\end{array}\right)(a-1)^{n}$, for all positive integers $n$.

Solution procedure given to the students: Write $\alpha=1+(\alpha-1)$ and apply the Newton's formula $(\mathrm{x}+\mathrm{b})^{n}=\sum_{i=0}^{n}\left(\begin{array}{l}n \\ i\end{array}\right) x^{n-i} b^{i}$, setting $\mathrm{x}=1$ and $\mathrm{b}=\alpha-1$.

Distracting problem: If $A$ and $B$ are as in the target problem, calculate $(A+B)^{2}$. -

Solution procedure given to the students: Operate the corresponding calculations.

CASE 3

Target problem: The price of sale of a good depends upon its total demand $Q$ and it is given by $P(Q)=\frac{1}{2} Q-50$, while the cost of production of the good is given by $C(Q)={ }_{\frac{1}{4}} Q^{2}+35 Q+25$. Find the quantity $Q$ of the good's total demand maximizing the profit from sale.-

Solution: The revenue from sale is equal to $P(Q) Q$ and therefore the profit from sale is given by $K(Q)=P(Q) Q-C(Q)$. The maximum of function $\mathrm{K}(\mathrm{Q})$ is calculated by using the derivatives. 
Remote analogue: A car is entering in a road having initial speed $50 \mathrm{Km} / \mathrm{h}$, which is changed according to the relation $U(t)=3 t^{2}-12 t+50$, where $t$ represents the time (in minutes) during which the car is moving on this road. Find the minimal speed of the car on this road.

Solution procedure given to the students: Calculate the minimum of the function $\mathrm{U}(\mathrm{t})$ with the help of the derivatives.

Distracting problem: The price of sale of a good depends upon its total demand $Q$ and it is given by $P(Q)=25-Q^{2}$. The price is finally fixed to 9 monetary units and therefore the consumers who would be planning to pay more than this price benefit. Find the total benefit to consumers.

Solution procedure given to the students: For $P=9$ and since $Q \geq 0$, it turns out that $Q=4$. metric units. Drawing the graph of the function $P(Q)$ (parabola) it is easy to observe that the total benefit to consumers is equal to $\int_{0}^{4} P(Q) d Q-4.9$ monetary units.

\section{References}

1. Czogala, E., Drewniak, J. \& Pedryz, W. (1982), Fuzzy relation equations on a finite set, Fuzzy Sets and Systems, 7, 89-101.

2. Genter, D. and Toupin, C. (1986), Systematicity and surface similarity in development of analogy, Cognitive Science, 10, $277-300$.

3. Gick, M.L. \& Holyoak, K.J. (1983), Schema induction and analogical transfer, Cognitive Psychology, 15, 1-38.

4. Hall, R. P. (1989), Computational approaches to analogical reasoning: A comparative analysis, Artificial Intelligence, 39 (1), 39-120.

5. Higashi, M. \& Klir, G.J. (1984), Resolution of finite fuzzy relation equations, Fuzzy Sets and Systems, 13, 65-82.

6. Holyoak, K. J. (1985), The pragmatics of analogical transfer, in: G. H. Bower (Ed.), The psychology of learning and motivation, Vol. 19, Academic Press, New York, pp. 59-87.

7. Kaufmann, A., (1975), Introduction to the Theory of Fuzzy Subsets, New York: Academic Press.

8. Klir, G. J. \& Folger, T. A. (1988), Fuzzy Sets, Uncertainty and Information, New Jersey: Prentice-Hall.

9. Novick, L. R. (1988), Analogical transfer, problem similarity and expertise, Journal of Educational Psychology: Learning, Memory and Cognition, 14, 510-520.

10. Prevot, M. (1981), Algorithm for the solution of fuzzy relations, Fuzzy Sets and Systems, 5, 319-322.

11. Sanchez, E. (1976), Resolution of Composite Fuzzy Relation Equations, Information and Control, 30, 38-43.

12. Subbotin, I. Ya. Badkoobehi, H., Bilotckii, N. N. (2004), Application of fuzzy logic to learning assessment, Didactics of Mathematics: Problems and Investigations, 22, 38-41.

13. Subbotin, I. Ya., Bilotskii, N. N. (2014), Triangular fuzzy logic model for learning assessment, Didactics of Mathematics: Problems and Investigations, 41, 84-88.

14. Subbotin, I. Ya. (2014), Trapezoidal Fuzzy Logic Model for Learning Assessment, arXiv 1407.0823[math.GM].

15. Subbotin, I. Ya. \& Voskoglou, M. Gr. (2014), Fuzzy Assessment Methods, Universal Journal of Applied Mathematics, 2(9), 305311.

16. Subbotin, I. Ya. (2015), On Generalized Rectangular Fuzzy Model for Assessment, Global Journal of Mathematics, 2(1), 65-70.

17. Voskoglou, M. Gr. (1999), The Process of Learning Mathematics: A Fuzzy Set Approach, Heuristics and Didactics of Exact Sciences, 10, 9-13.

18. Voskoglou, M. Gr. (2003), Analogical problem solving and transfer, in Gagatsis, A. \& Papastavridis, S. (Eds.), Mathematics in the Modern World: Didactics, Life and Society, Hellenic Mathematical Society, Athens, , pp. 295-303.

19. Voskoglou, M.Gr.(2017), Finite Markov Chain and Fuzzy Logic Assessment Models: Emerging Research and Opportunities, Columbia, SC: Createspace.com. - Amazon.

20. L.A. Zadeh (1971), Similarity relations and fuzzy orderings, Information Sciences, 3, 177-200.

\section{ЗАСТОСУВАННЯ РІВНЯНЬ НЕЧІТКИХ ВІДНОШЕНЬ ДО ОЦІНКИ УМІНЬ РОЗВ'ЯЗУВАТИ АНАЛОГІЧНІ ЗАДАЧІ} Майкл Гр. Воскоглу

Вищий технологічний освітній інститут Західної Греції, Патрас, Греція

Анотація. Аналогічні міркування важливі взагалі для творчості та наукового відкриття, i, зокрема, це дуже корисний спосіб розв язування математичних задач шляхом знаходження у пам'яті аналогічних задач, що розв'язувалися в минулому, та адаптації їх розв'язань до даної задачі. з іншого боку, оцінювання студента є важливою задачею освіти, оскільки воно є не тільки соціальною вимогою та потребою, а й допомагає інструкторам у розробці майбутніх планів щодо більш ефективної методики навчання. Проте часто інструктор не впевнений у точному оцінюванні, яке відповідає кожному студенту. Тому оцінювання студента характеризується ступенем нечіткості та / або невизначеності. Отже, нечітка логіка, обумовлені ї̈ властивістю характеризувати неоднозначні реальні життєві ситуації з кількома значеннями, стає доступним ресурсом оцінки, який слід застосовувати в таких невизначених випадках.

У даній роботі використовуються рівняння нечітких відношень як інструмент оцінки умінь розв 'язувати аналогічні задачі студентами. Рівняння нечіткої відношень отримуються як композиція бінарних нечітких відношень, які є нечіткими множинами, визначеними декартовим добутком двох чітких множин. Композиції бінарних нечітких відношень зручно представляти в термінах матриць їх членів. У цих композиціях використовуються ті самі елементи матриць членів, які будуть використовуватися при регулярному множенні матриць, проте операції добутку та суми замінюються тут операціями знаходження мінімума та максимума відповідно. Поняття рівнянь нечітких відношень було вперше запропоновано Санчесом у 1976 рочі, а пізніше досліджувалося і іншими дослідниками.

Застосування на уроках та інші відповідні приклади також представлені у статті, що ілюструє результати автора. Також дана робота пов'язана з нашими попередніми дослідженнями з використанням декількох інших методів нечіткої логіки як інструментів для оцінювання студентів.

Ключові слова: нечіткі множини, нечіткі бінарні відношення, рівняння нечітких відношень, аналогічні міркування, решение аналогічних задач, оченка студентов. 